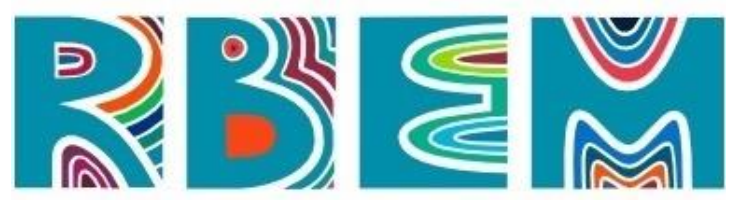

REVISTA BAIANA DE EDUCAÇÃO MATEMÁTICA

\title{
ARTIGO
}

https://doi.org/10.47207/rbem.v1i.10363

\section{TRIGONOMETRY IN RURAL SPACE: implications of contextualized mathematics education}

\author{
MOTA, Charles Maycon de Almerida \\ Universidade do Estado da Bahia - Doutorando em Educação e Contemporaneidade. \\ ORCID: http://orcid.org/0000-0001-5927-3466. E-mail: charlesmaycon22@ hotmail.com. \\ SILVA, Fabrício Oliveira da \\ Universidade Estadual de Feira de Santana - UEFS. Doutor em Educação e Contemporaneidade. \\ ORCID: http://orcid.org/0000-0002-7962-7222. E-mail: fosilva@uefs.br.
}

\begin{abstract}
This text aims to understand how the experiences with pedagogical workshops on taching mathematics in rural areas favored the teaching and learning of geometry by undergraduate in Pedagogy and by elementary school students. The text reflects the contexts of the countryside, showing how this can be enhanced as a locus for valuing actions in teaching that go beyond the school walls and expand by the contexts of life of their students. The methodology of this work comprises the realization of a pedagogical workshop with a course load of 12 hours, held at Sítio Mata da Lua by graduates of the Pedagogy Course in the Teaching of Mathematics discipline, given to students of the 9th grade of Elementary School II and the High school. The workshop was the research device used to enable reflections on the development of teaching practices that aim to theorize and value the students' context through a study on the concepts of trigonometry, plane geometry and surface measurements in situations and experiences in the fields. We take the reports of teachers and students who participated in this workshop as an element of analysis. It is concluded that the teaching of mathematics generates meanings for the student when the context in which he lives is taken into consideration for the construction of school knowledge. The countryside was understood as a locus of teaching in mathematics, enabling students to create connections between th knowledge of the countryside and the knowledge of trigonometry, in a construction of significant learning about mathematical knowledge.

Keywords: Mathematics teaching. Initial formation. Contextualized education. Teaching in the country.
\end{abstract}

\section{TRIGONOMETRIZANDO NA ROÇA: implicações de uma educação matemática contextualizada}

Resumo: O presente texto busca compreender como as experiências com oficinas pedagógicas de ensino de matemática em espaço rural favoreceu o ensino e aprendizagem da geometria por licenciandos de Pedagogia e por estudantes do ensino fundamental. O texto reflete os contextos da roça, evidenciando como isso pode ser potencializado como lócus para valorização de fazeres na docência que extrapolem os muros da escola e se ampliem pelos contextos de vida de seus estudantes. Compõe a metodologia deste trabalho a realização de uma oficina pedagógica com carga horária de $12 \mathrm{~h}$, realizada no Sítio Mata da Lua por licenciandas do Curso de Pedagogia na disciplina Ensino da Matemática, ministrada para estudantes do $9^{\circ}$ Ano do Ensino Fundamental II e das três séries do 


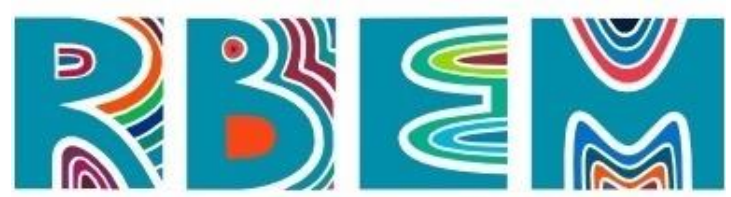

REVISTA BAIANA DE EDUCAÇÃO MATEMÁtICA

Ensino Médio. A oficina foi o dispositivo de pesquisa utilizado por possibilitar reflexões acerca do desenvolvimento de práticas docentes que com vistas a tematizar e valorizar o contexto dos alunos através de um estudo sobre os conceitos de trigonometria, geometria plana e medidas de superfícies em situações e vivências na roça. Tomamos os relatos de professoras e estudantes que participaram dessa oficina como elemento de análise. Conclui-se que o ensino de matemática gera significações para o estudante quando o contexto em que ele vive é levado em consideração para a construção de saberes escolares. A roça foi entendida como um lócus de atuação da docência em matemática, possibilitando que os estudantes criassem relações entre saberes da roça com os da trigonometria, numa construção de aprendizagens significativas sobre os saberes matemáticos.

Palavras-chave: Ensino da Matemática. Formação Inicial. Educação contextualizada. Docência na roça.

\section{TRIGONOMETRIZANDO EN EL ESPACIO RURAL: implicaciones de la educación matemática contextualizada}

Resumen: Este texto busca comprender cómo las experiencias con talleres pedagógicos de enseñanza
de la matemática en áreas rurales favorecieron la enseñanza y el aprendizaje de la geometría por parte
de los estudiantes de pregrado de Pedagogía y de la escuela primaria. El texto refleja los contextos del
espacio rural, mostrando cómo estes se pueden potenciar como un locus para valorar acciones en la
enseñanza que van más allá de los muros de la escuela y se expanden por los contextos de la vida de
sus alumnos. La metodología de este trabajo comprende la realización de un taller pedagógico con una
carga de trabajo de 12 horas, realizado en el Sítio Mata da Lua por estudiantes del Curso de Pedagogía
en la disciplina de Enseñanza de las Matemáticas, impartido a alumnos del $9{ }^{\circ}$ grado de la Escuela
Primaria II y de los tres grados de la Escuela secundaria. El taller fue el dispositivo de investigación
utilizado para posibilitar reflexiones sobre el desarrollo de prácticas docentes, con la intención de
tematizar y valorar el contexto de los estudiantes a través de un estudio sobre los conceptos de
trigonometría, geometría plana y medidas de superficie en situaciones y experiencias de campo.
Tomamos los informes de profesores y alumnos que participaron en este taller como elemento de
análisis. Se concluye que la enseñanza de las matemáticas genera significados para el alumno cuando
se toma en consideración el contexto en el que vive para la construcción del conocimiento escolar. El
espacio rural fue entendido como un locus de enseñanza en matemáticas, que permite a los estudiantes
crear relaciones entre los conocimientos del campo y los de la trigonometría, en una construcción de
aprendizajes significativos sobre el conocimiento matemático.

Palabras clave: Enseñanza de las matemáticas. Formación inicial. Educación contextualizada. Docencia en el campo.

\section{Introduction}

In the contemporary educational scenario, it has been a recurrence to engage in discussions that consider teaching and learning as processes that are transversalized by a contextualized education. In the case of mathematical education, there is a need for teaching to be materialized in innovative perspectives, which according to Alves and Cavalcante 


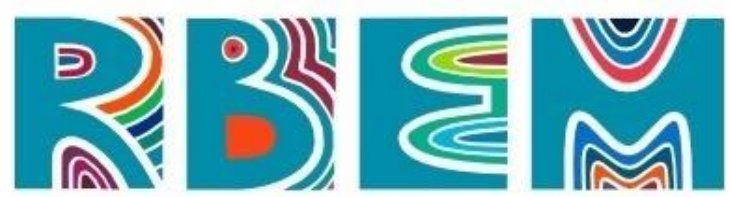

REVISTA BAIANA DE EDUCAÇÃO MATEMÁtICA

(2017) gain notoriety in the field of mathematical education when teachers consider the learning context and the real needs of learners. In this sense, the idea of teaching implies a dimension of considering the contexts in which learning should take place. These are, therefore, contexts that enable understandings and the attribution of meanings to what is learned, which is based on an idea of innovation linked to the understanding of contextualized doing.

Still according to the studies developed by Alves and Cavalcante (2017), it has been quite necessary that educators seek to develop teaching practices that enable learning that is also anchored in the perspectives of innovation, understood as basing on the construction of elements that facilitate teaching practice, in order to contextualize teaching and think about the valuation of living spaces and how these spaces can be taken as places of learning, allowing the student, from that, to innovate in the processes of understanding and development of learning. It is in this line of thought that the present work brings to the scene the reflections around defending a contextualized education, which takes into account the production of knowledge from the experiential learning woven in the school routine.

The idea of everyday life evokes in this work the transcendence of the school space, beyond the school wall, seeking to expand the sense of school to other formative spaces in the teaching of mathematics, as is the case of the countryside, which rises as an enabling space for that teaching materializes in principles of innovation, as well as the contextualization of practices that are effected by anchoring the knowledge that students have for experiencing the countryside in their daily lives. In this logic, the countryside is an educational space that produces knowledge, from which students develop other mathematical knowledge, anchoring it in those who already have experiences and understandings. This idea is based on the perspectives of meaningful learning, which according to Ausubel (1982) is the one to which the apprentice attributes meaning by starting from something he already knows, anchoring elements, to build new knowledge, and in this to develop learning that has meaning for itself, which emerges from the condition of learning and, therefore, valuing what is learned.

It is in this direction too, that mathematical education is effective in weaving the production of tactics and cunning that students develop to learn mathematics. It is about seeking in the school to develop actions that enable the student to deal with the learning processes. This implies a recognition that students' everyday life is invented for survival in the 


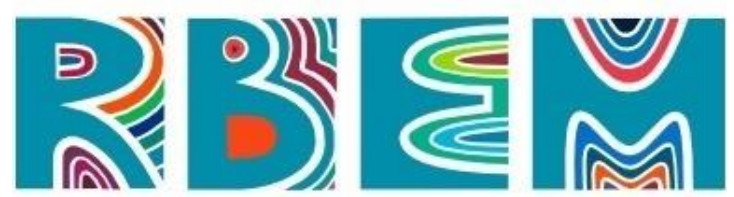

REVISTA BAIANA DE EDUCAÇÃO MATEMÁTICA

learning factory, which generates the conditions for them to produce their own tactics to learn mathematics and realize that they can apply the knowledge of the area in their life contexts in the fields ${ }^{\mathrm{i}}$. In this logic, it is possible to see how learning contexts generate possibilities for learning to take place, in mathematics, in ways that are mirrored in the invention of everyday life on Certeau (1994), when considering what the capitalist system needs to be understood to generate conditions that man there produces his tricks and ways of living in such a system.

Something similar happens at school when students need to learn mathematics, creating through it, tactics and cunning to mean what they learn, in a given experiential context. It is from there too, that the ideas of experiences, while events that touch, mark, transform the learning subject, are basic and corroborate for the student to have protagonism, in the proper ways that each one finds to build their ways of studying and learn mathematics at school, which expands in this work to the space of the countryside. The school is the countryside, it is the life of the apprentice that is reframed, both by teachers in initial training for teaching, as well as reframed by each student of the basic school, resident in rural communities, who seek in their own experiences to learn mathematics.

In this area, the present work constitutes a research that was developed through the realization of a workshop proposed in the discipline Teaching of Mathematics developed by undergraduate students of the Pedagogy course of the Regional College of Riachão do Jacuípe - FARJ, in the pole of Várzea do Poço - BA. The centrality of this proposal is in the reflection from the experience with the development of teaching practices in non-formal spaces in order to experience the planning and evaluation processes related to the area of Mathematics, using the contextualization of contents to enable students, who live in rural areas, an experience that triggers the development of meaningful learning.

The question that mobilized the present study was raised by the licensors themselves, executors of the workshops, when they asked themselves: How can the teaching of trigonometry generate meaning for students in the countryside if it is woven in the countryside itself? How will students' prior knowledge make it possible to understand the concepts of geometry? How can the teaching of mathematics contextualized by the daily life of the countryside favor a contextualized learning? 


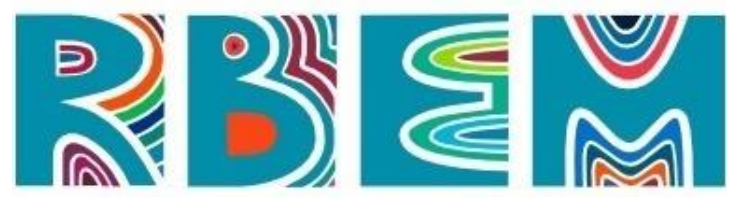

REVISTA BAIANA DE EDUCAÇÃO MATEMÁtICA

Anchored in these questions, the text aimed to understand how the experiences with pedagogical workshops teaching mathematics in rural areas favored the learning of geometry by elementary school students.

The text is divided into four sections, plus this introduction. Therefore, in the following section, we present the methodological weaves of the workshops, showing the subjects, the scenarios and the operating mode in which the study was constituted. In the second section, we discuss a contextualized education in the municipality of Várzea do Poço, the locus of the site where the present study was developed, discussing the principles of an education that is woven into the tactics and cunning of everyday school, focusing on strategies that students and teachers in initial training develop to teach and learn. In the third session, we present the results, highlighting the research findings in the web of discussions about school routine and significant learning, weaving aspects of initiation into teaching, guided by the experiential training policy in adherence to situations of contextualized education. Last but not least, we make the final remarks.

\section{Methodological trail}

The methodological weaving of the present study took place from the pedagogical workshop device. Therefore, the workshop was used to favor the practical development of the teaching and learning process of geometry, in a real context of the countryside, therefore daily and dynamic for the students' lives.

The workshop was held at Sítio Mata da Lua ${ }^{\mathrm{ii}}$ with the aim of reflecting on the development of teaching practices that enhance the students' context through a study on the concepts of trigonometry, flat geometry and surface measurements in situations and experiences in the countryside. Therefore, this work was developed with undergraduate students of the Pedagogy course in the Teaching of Mathematics discipline, in which such undergraduates would invite students who are connected to non-formal education spaces in rural spaces in the municipality of Várzea do Poço - BA.

The students who participated in the workshop were enrolled in schools located at the headquarters of the municipality and were in the 9th grade of Elementary II, 1st, 2nd and 3rd years of high school, in an age range of 14 to 19 years old, residents of rural areas who daily 


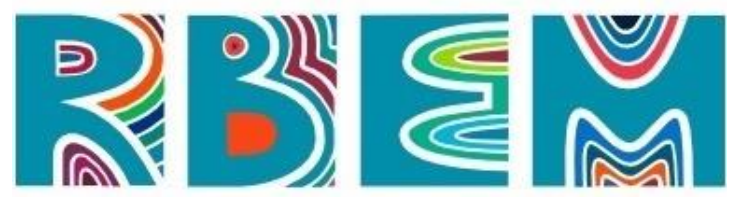

REVISTA BAIANA DE EDUCAÇĀO MATEMÁTICA

attend the route to access the city's schools. We clarify that, for reasons of ethics in research, the names of collaborators are fictitious.

It is worth mentioning that the workshop was held in the $12 \mathrm{~h}$ period of involvement between mediators and students, being organized by planned moments between socializing discussions, exploring the site's pedagogical potential, carrying out practical activities and some lists of exercises created from experienced situations in the countryside itself.

At first, we made a mystique that used seeds, fruits and elements existing in the countryside to reflect on the emergence of mathematics, in a contextualization of the history of mathematics, so that students would be presenting their knowledge about their space of life and what they consider to be mathematical knowledge based on what they experience in the countryside. This was a moment of interaction between the students, since they are from different classes, as well as interaction with the workshop mediators. Such dynamics favored the idea that when there is a pedagogical proposition that takes the contexts of life and its elements as a starting point for the construction of new knowledge, we are encouraged to build meaningful learning.

In the second moment, a visit was made to the site space, exploring all the places where we could make demonstrations of situations in which trigonometry could be seen. In matis this logic, calculations and measurements were performed to find the value corresponding to the height of old trees and trunks in the middle of the forest from its shadow or fallen part that was still attached to the ground, in a triangular simulation. We used gates, roofs of stalls and corrals, we did simulations with ropes on the ground to form triangles, find values of hypotenuse and legs.

In the third moment, we met on the balcony of the house on the farm and began to discuss the concepts of trigonometry, resolving doubts and helping in the difficulties of what the students still had. That was the moment when we made lists of exercises from the simulations that were made in the spaces of the site, as a way to improve the presented knowledge and apply formulas of concepts of mathematics. This moment culminated with the mini competition to evaluate the whole process proposed in the workshop. It was the moment when the tactics and cunning of each student were made visible to produce results of the exercises, using the knowledge of everyday life. It was also a time for the undergraduate 


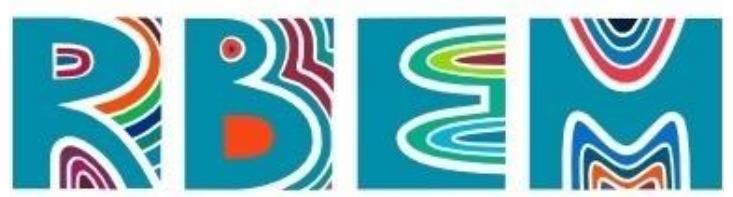

REVISTA BAIANA DE EDUCAÇÃO MATEMÁtICA

students to realize the construction of different teaching and reflection strategies for the production of mathematical learning.

During these moments, we took the opportunity to collect some reports about the training movement that was taking place in the context of the workshop. Such reports were also constituted here, as elements of analysis to understand how the teaching of trigonometry can generate meanings for students in the countryside if they are woven in the countryside, as well as re-signifying the knowledge that these students had about their life contexts, generating meaningful learning.

The workshops had a reflexive weave anchored in a movement to think paths for teachers in initial training as a search for their own forms that would enable the development of teaching actions. With trigonometry in the countryside, the pedagogical actions were anchored in a paradigm of understanding contextual teaching, woven from the logic of understanding and using tactics of students in view of the knowledge of the countryside, then the daily knowledge of their lives. Thus, the conception of teaching practice was anchored in the understanding of mathematics teaching centered on a contextualized education proposal as a possibility for enhancing the previous knowledge that students from the countryside bring with them.

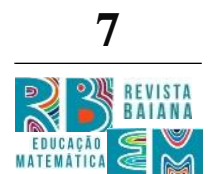

To propose a training space that would be placed as an insurgency in the sense of breaking urban-centric logics, valuing the coutryside, knowledge and experiences that students from the farm produced throughout their lives is presented here as a formative power to think about teaching mathematics based on the principles of contextualized education. In addition, it arises as a provocation of a formation that considers tactics and astuteness reconfiguring contributions of the contexts of teaching in contemporary times.

This work had as its initial proposition the discussion about the concepts of Trigonometry and its elements, which comprised the resumption of other Mathematical contents from a dynamic that involved the elements found in the forest and around the site and which served for a resumption on the history of mathematics and the reasoning that such an area was and will always be useful for the advancement of science and the evolution of humanity.

Right after the presentation on the concepts and understanding of the formulas that would be used during the practical experiments, the space of the site where we could use 


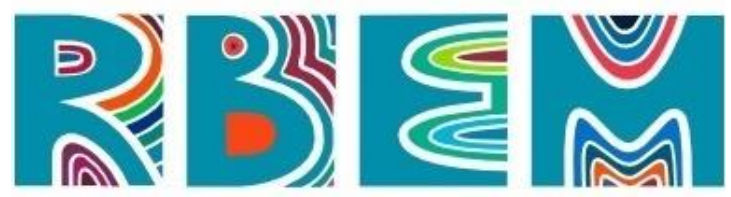

REVISTA BAIANA DE EDUCAÇÃO MATEMÁtICA

examples and situations related to the contents that would be worked on was presented. At this moment it was proposed that students write down their doubts and/or create new problem situations, following the same themes, some other situations were exposed that explored flat and three-dimensional geometry in various locations on the site.

After all the experiments, the students were divided by teams to carry out a mini competition as a way to evaluate the teaching and learning process through this didactic proposition, where we would make the corrections of all the questions presented in the late afternoon as a review of all content covered.

In this way, we also proposed an evaluation of the workshop to be carried out by the participants, but as the time became short for the exploration of so many situations, it was suggested that those who were comfortable making their impressions about the moment, some students positioned themselves and emitted these impressions so that they valued the project, emphasizing how their learning had happened. But as technology was present throughout our work, where these same students were always photographing their participation and posting on social networks, we were surprised by a situation of evaluation of the project and its network methodology.

There are many discussions about pedagogical practices that propose teaching methodologies that enable the development of meaningful learning in the area of Mathematics, such discussions have made us reflect on the competences and skills that the curriculum in this area requires of our students, thus, we can notice that it is necessary to reformulate the curricular and pedagogical proposals in schools, in order to meet the different realities that each school institution is inserted in, as we must consider the necessary possibilities that an individual needs to make relationships between your previous knowledge and those presented to you in order to build new knowledge, so we can emphasize thinking from the dialectic method (MORETTO, 2007).

It is important to emphasize that, in the course of these discussions mentioned above, there are already some advances that have contributed strongly to demystifying this area of knowledge. In this sense, we can mention public policies for initial and continuing education for mathematics teachers, example of the Mathematics Pro-Literacy course that: 


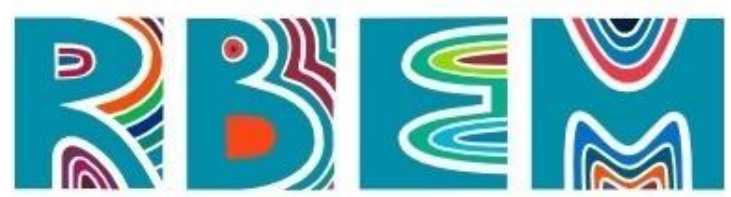

REVISTA BAIANA DE EDUCAÇÃO MATEMÁtICA

foresees the use of the principle of problematizing the contents and daily practices of teachers for teaching mathematics. It seeks to signify practices and content without losing the scientificity necessary for the life of the citizen, bringing to the fore new readings with new approaches to the teaching of mathematics (BRASIL, 2007, p. 9).

We cannot fail to mention the contribution of the Bahian Mathematics fairs that has enabled a new reflection on a differentiated pedagogical practice, which would offer us the conditions to contemplate several teaching practices that are based on contextualization, emphasizing products built from the association between the elements of the lived world and the elements of the systemic world.

These two initiatives have been considerable for our teaching practices to value contextualized education, proposing a new reconfiguration in the process of teaching and learning mathematics.

\section{Characterization of the municipality and its contextualized education proposal}

Considering that Várzea do Poço - BA is characterized as a rural municipality, being located 205 miles from the capital, having a territorial area of $220 \mathrm{~km}^{2}$, a population of 8,600 inhabitants, its economy is strongly based on family farming and livestock, its proposal education is based on Paulo Freire's theories to support the contextualized education methodology based on the Project "The education we want, the way we are" - an initiative by the Diocese of Rui Barbosa implemented in the city in 2003 in the rural schools and expanded to all levels of basic education in the municipality.

Starting from the premise that it is necessary to value the different places of experience, as well as the daily practices of work and leisure, of the people who live in the polygon of the drought, the applicability of contents that make up the formal curriculum in the students' daily life, from the 9th year of elementary school to the 3rd year of high school who live in rural areas of the municipality, arises as a problem. Thus, it was proposed to develop a study workshop to discuss Trigonometry and Geometry, assuming the orientation for the use of mathematical concepts on these contents and their application in the activities that many of these students already develop in their place of experience. 


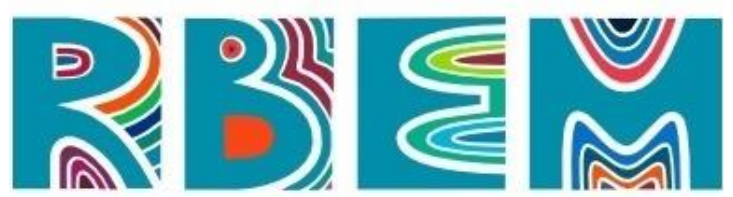

REVISTA BAIANA DE EDUCAÇÃO MATEMÁTICA

To do so, we rely on authors who discuss contextualized education in the semiarid region, as we realize that the great difficulty, today in the Final Series of Elementary and Secondary Education, is to develop a work methodology that can overcome the old models of repetitive classes that only the textbook and the blackboard are used as a working tool, because "the school is losing legitimacy in the eyes of its students, as they become aware of the delay in the development of the society it is supposed to serve, as well as the retrograde learning methods that he continues to adopt" (PAPERT Apud GOMES \& SILVA, 2013, p. 454).

Therefore, a proposal like this brings several contributions to the development of new practices in the teaching of mathematics, problematizing the reality of our students and offering subsidies for meaningful learning. Thus, the principles of contextualized education are anchored in reflections on school daily life, woven into a dynamic conceived in / by the operations that students do in the countryside to transpose the knowledge they acquired there through contextual experiences for learning trigonometry. These are operations that students carry out, both those who are graduates, who perform teaching operations, and those in elementary school who perform learning operations.

The invention of everyday life has its roots in a research that arises from the questioning of users' operations, supposedly given over to passivity and discipline. On the one hand, analysis shows that the relationship, always social, determines its terms, and not the other way around. On the other hand, the issue addressed refers to modes of operation or schemes of action and not directly to the subject who is the author or vehicle. In this way, the work gains prominence from the principle of having as its primary objective that of making explicit the combinations of operations that also compose, without pretending to be exclusively, a "culture" and exhuming the action models characteristic of users.

Reading the text allows us to understand the dimensions of everyday life and its practices, since the idea that interrogation about daily practices was, at first, negatively thought by the need for not finding the cultural difference in groups that raises the "counterculture" flag. Certeua (1994) proposes and investigates the uses that subjects in a factory relationship make of cultural products and what they "manufacture" from cultural practices. It is from this logic that we understand the conception created for the "arts of making". 


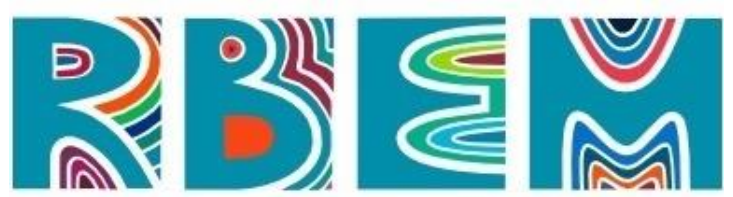

REVISTA BAIANA DE EDUCAÇÃO MATEMÁtICA

In this direction of analysis, the cultural products used in daily life are appropriated and transformed by the subjects based on tactics and ways of doing that are ancient, but which provide conditions to produce new practices and new arts. In them, Certeau (1994) does not see the massified, passive subjects disciplined by the cultural industry or by mechanisms of power. The daily practices and the "arts of doing" point to a characterization of these subjects as being producers, or in their discourse, as "another production".

Certeau's work (1994) shows that the presence and circulation of a representation does not suggest what it is to its users. He points out that the products are also used by the subjects who do not manufacture them. It is from this condition that the author proposes the reflection that it is only then that one can analyze the difference or similarity between the production of the image and the secondary production that is hidden in the processes of its use.

Thus, "ways of doing" constitute the thousand practices by which subjects, for Certeau (1994) users, reappropriate the space organized by the techniques of socio-cultural production. In his analysis, "popular culture" is constituted and presents itself differently, as well as a whole literature called "popular". It essentially consists of "arts of doing" this or that, that is, in combinatorial and utilitarian consumption. In this logic, we infer that the countryside is seen as a great stage in which the "arts of doing" are re-signified among the subjects who are there, who appropriate the school routine and develop different ways of culturally conceiving new practices of teaching in the ways to learn mathematics through the knowledge already produced there.

Educational practices are taken as elements of reflection for teachers in initial training, who instead of being in a logic of reproducing techniques and ways of teaching, inaugurate a reflective culture on how students learn inserted in their experiential universes of learning who succeed in the countryside, seen as an educational space, which, from their daily lives, generates new "arts of doing" for both those who learn and those who teach. It is learning about teaching and how to teach mathematics contextually, which appears as a combining element of a culture that does not excel in merely reproducing practices, but which promotes a reflection of how one learns significantly when education develops in a contextual perspective, having the everyday life as the ways of producing new practices.

This became visible in the workshops, from which the pedagogy students realized that: 


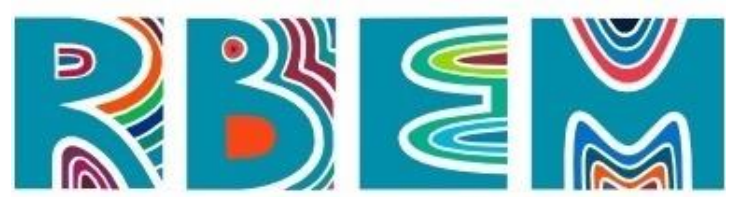

REVISTA BAIANA DE EDUCAÇÃO MATEMÁTICA

Carrying out a proposal like this workshop, which allows us to understand how students can learn from what already exists in the coutryside, based on what they already present as previous knowledge about mathematics in their daily lives is very gratifying for us, who are involved in a teacher training, as it is an opportunity to understand how we can use what everyday life has to teach concepts and formulas, making teaching mathematics more pleasurable and in an engaging way. (Report by Márcia, 2018)

The students showed that:

Learning mathematics the way we are learning here in the countryside, seeing how we can apply the calculations we learn from the teachers' explanations is much more interesting because we can learn and see how it is done in practice, in the countryside where we live. It is not like something from another world that we will only learn if we memorize formulas and do those homework in math books. (Report by Pedro, 2018)

Márcia and Pedro emphasize how teaching and learning are potentiated when they are woven into context by the daily reality experienced. If for the teachers in training, the workshop generated ways of apprehending tactics for teaching mathematics, for the students it is the valorization of the knowledge that they have in dealing with the countryside reality the basic element to develop other learning. They are "arts of doing" in teaching and dealing with the fields that generate the possibility of giving a new meaning to mathematics and its contribution to students' lives.

The "arts of doing" in the teaching initiation of undergraduate teachers in pedagogy reveal the way in which learning operates in initial teacher training with a special focus on the crossing of mathematics education in the early years of elementary school. Thinking about a teaching that favors meaningful and contextualized learning of mathematics, also implies recognizing the formation of teachers in the experiential movement of everyday school, in which the insurgencies of teaching practice are unveiled in the formative crossings that leave the university wall and happen in the countryside, in the school of life, in order to favor, as Silva and Rios (2018) defend, the experiential learning of teaching.

In the next section, we focus on some results about the process of initiation to teaching in the "arts of doing" of Pedagogy graduates, who seek in the workshops to create a scenario of tactics and abilities to teach young people in the countryside a trigonometry that is 


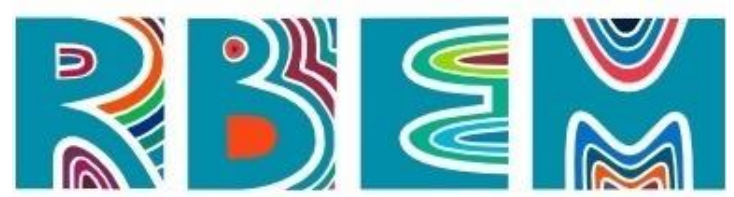

REVISTA BAIANA DE EDUCAÇÃO MATEMÁtICA

resignified by the knowledge that each young person has and is able to relate to the content that is valued at school.

\section{Arts of doing undergraduates in mathematics education}

The way of making the teaching of trigonometry happen in the rural space is unique in each subject in formation, given the context of analysis that is established in the daily life that denies the idea of repetition, as if the daily life was a sameness. There is a culturally constructed logic that it is necessary to develop new ways of doing and conceiving teaching through a process of contextualizing teaching action. In the perception of teachers in initial training, this is due to the self-evaluative and reflective condition that they develop in the teaching process, which consider the knowledge of children and young people who live in the countryside. It is, therefore, in the daily life of the coutryside that it is possible to culturally appropriate the educational practices that develop there and that need to form the basis for others that are not merely reproductive.

Hence the logic of anchoring the everyday view of educational practices developed at school to the creative and contemporary ways of the "arts of doing" described and analyzed by Certeau (1994) and by Agnes Heller (1997) in other times, contexts, but in the same essence of understanding that everyday life is not characterized by repetitive sameness, which does not give way to creativity.

According to what Agnes Heller (1997) recommends, daily life is not a mere logic of reproducing events. Thinking about the school in this perspective means considering that the organizational practices of teaching work are not done in the same way and only within the school walls. If this is true, it will be so true that training in school life is made up of movements that are not characterized by mere repetitions. Thus, each teacher, each class, each organizational practice is produced in a logic of univocity, because one thing is not always done in the same way. In their testimonies, the undergraduate students reveal how the teaching of mathematics can be configured in different contextual aspects, in addition to the school wall, producing events that come from the meaning of each child when they can relate their knowledge to school knowledge.

In this perspective, the teachers revealed that the workshops made it possible to perceive that children know the notions of area, perimeter, length, notion of size, anchored by 


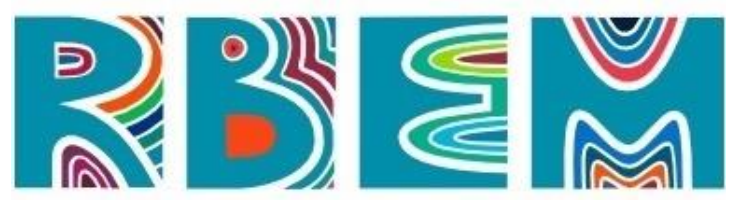

REVISTA BAIANA DE EDUCAÇÃO MATEMÁTICA

the knowledge they produce in their daily life in the countryside. It is from this knowledge that the teaching practice is nourished and built inventively and creatively, bringing this practice closer to the conceptions of innovation discussed in their study Alves and Calvalcante (2017). In her account, teacher Clara considers that:

Promoting a workshop in a rural area to see in practice how we can apply mathematical concepts and demonstrate to young people who live in the countryside the usefulness of mathematical knowledge is of great importance in our training, especially with regard to the movement of mathematics teaching based on contextualized education proposals, for offering us the conditions to reinvent doing in teaching, thinking about the use of the knowledge that each student brings with them. (Clara's account, 2018)

The work with trigonometry makes up the arsenal of contents worked in the period, in which the compositional nature of the fundamental concepts that children must learn in mathematics is considered. Thus, teaching moves in the direction of valuing knowledge, the contextual knowledge of the child, who has the opportunity to perceive how mathematics is linked to his daily knowledge, with which the child deals in the countryside, with the family. It is from this condition that the child's understanding is observed when he understands that the school prepares for life, so that he can deal with situations in which he lives.

In this direction, there are reports from the children stating that it was in the fields that they understood what the teacher was teaching about the area, about what the geometric shapes that she knew by other means, by other names. These are the knowledge of the farm that is giving new meaning, generating conditions for meaningful learning, as advocated by Ausubel (1982). In Gisele's report, this is evident when the child, speaking of what she thought of the workshops, expresses that:

I never thought that these thematic of trigonometry could be presented to us in such an interesting way and, here in the countryside, through practical demonstrations such as the example we had to calculate the height of the licurizeiro foot, forming a triangle with a rope tied at the top of its trunk with the shadow that trunk made. That's when I saw mathematics present in all places of my life. Learning mathematics like this is very interesting because we leave that thing of staying in the classroom with the book in hand and put the concepts into practice. (Report by Gisele, 2018) 


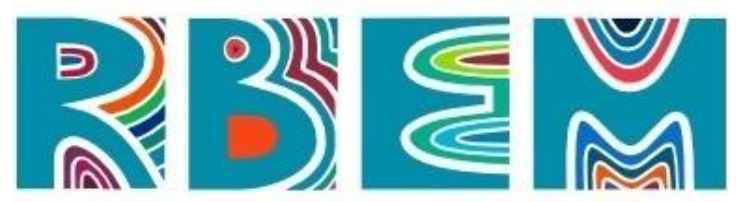

REVISTA BAIANA DE EDUCAÇĀO MATEMÁTICA

It is at school, in the countryside, consequently in their daily lives, cultural dimensions of the teaching and learning process that are conveyed by teachers in initial training, who learn from children in their daily lives in the fields and teach them to transcend this knowledge, making them to understand mathematics from other places, but who are not far from the ones that each student lives in their school routine, especially in their daily work with in the countryside.

In this way, teaching learning, and in the context in vogue here, teaching to work on geometry teaching issues contextualized with the knowledge of the countryside, emerges as a process that is resized from the experiences achieved in school routine. Thus, the licensee creates new ways of doing things, which are integrated with the way each one understands and develops the knowledge for teaching. From the point of view in which daily life is taken into account in some works, Alves (2003) tells us that:

The works that are concerned with the daily life of the school and with the different cultural modes present there start, then, from the idea that it is in this process that we learn and teach to read, write, count, ask questions to the world around us, to nature, to the way men / women relate to each other and to it, to poetize life, to love the other. That is, at the same time that we reproduce what we learn from other generations and with the social lines that determine hegemonic power, we are creating, every day, new ways of being and doing. (ALVES, 2003 p. 66)

Many actions are developed at school in their daily lives, which are culturally understood as repetitions of certain practices. Thus, we see the realization of pedagogical weeks, parents' meetings, celebrations, cultural activities, class councils, teachers' meetings, development of educational projects, among others. The school in a logic of common sense would be compared to a factory dimension in which it produces and reproduces its actions in a cadence characterized by repetitions. But this would be a wrong analysis and would deny the dimension of understanding that subjectivities are at school.

The "arts of doing" are unique in everyday life, just as the individuals who are there are unique. Thus, everyday life is seen in a heterogeneity that promotes the production of new ways of making school cultural practice develop from the ways that each appropriates the educational universe, especially in the on-screen study of the universe of learning mathematics. For the subject in training, this happens in a vision of empowerment of knowing 


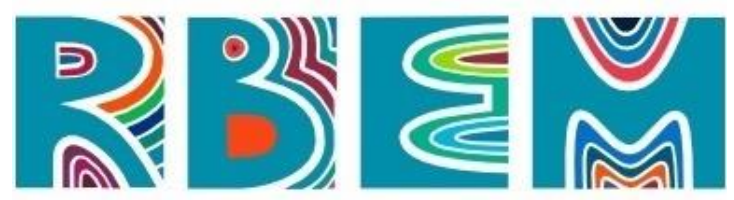

REVISTA BAIANA DE EDUCAÇÃO MATEMÁTICA

how to do, which demarcates the senses for what is learned from the profession for which he is graduating.

Alves \& Garcia (2000) when dealing with daily life, start their reflections drawing attention of readers to the fact that:

Much is said about the school, outside the school, away from the school, often from an absolute ignorance in relation to what happens inside the school every day, when the professionals who work in it, the students and their parents, and the community where it is inserted are interacting daily. The school that so many talk about is a simplification based on a reductionist paradigm that ignores everything that happens and is created in this space/time of learning and teaching, of the relationship of subjectivities, of encounters and mismatches, of socialization. (ALVES \& GARCIA, 2000, p. 7)

For these authors, it is necessary to be at school, to live it on a daily basis, as it is only there that one can have an appropriation of ways of learning and teaching, which is produced in the context of socialization and subjectivities that are constituted by relationships between so many subjects who live there. It should be clarified that the garden is also a school, it is a non-formal space, but of significant learning in everyday life, and why not say school life. Taking such a position on the school in its daily dynamics implies understanding that teacher training must also happen anchored in the logic of the school's day-to-day. It is to leave a dominant dimension of training that is produced in a curriculum that the school lives little beyond its walls to give that curriculum conditions to establish training based on a reality that can only be known within the school. This concerns the teaching learning processes that consider the relationship between school subjects as a way of creating new "arts of doing" that are also processed in creativity and in the condition of producing perspectives from those that are observed and analyzed in the school routine.

And it is in these perspectives that the teaching of trigonometry in the countryside starts to have a meaning for those who teach, as for those who learn. It is worth noting that the contextualization of mathematical content can stimulate students in the midst of the process of motivation to learn what is being taught, especially if contextualization is taken into account as an element of particular experiences lived for the students, as is the case of the knowledge lived by children and young people from the countryside. This is the perspective that Tufano 


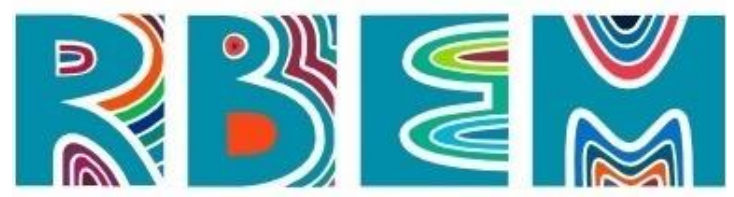

REVISTA BAIANA DE EDUCAÇÃO MATEMÁtICA

(2001, p. 47) adopts when considering that contextualization is a particular act, it is an act of displacement that is produced to experience other experiences.

Each author, writer, researcher or teacher contextualizes according to their origins, their roots, their way of looking at things very carefully. And the prudence of teachers in initial training to achieve contextualization of the teaching process of trigonometry based on the particularities experienced by the child from the countryside shows the displacements that are necessary to be made by teachers who are undergoing initial training. This will reveal the way in which each teacher builds paths to generate contextualization and meaningful teaching, especially in the area of mathematics that supports the principles of knowledge produced by a child who lives in the countryside.

The contextualization of the content itself, reflects a certain importance in relation to the daily life experienced by students, since it allows the student to understand that what is learned in the classroom has application in their practical life, in the work of the countryside and of the ways in which they live this space and contextualizes it. Thus, it is possible to infer that contextualized teaching enables students to develop resources that prepare them to face the challenges imposed and existing in the world in which they (students) live.

\section{Final considerations}

The development of proposals that are based on the conceptions of contextualized education, involving the students' daily life, provides us with several reflections on how important it is to propose classes that surpass planning based on a non-critical pedagogical trend. Therefore, it was evident that this initiative offered conditions for an exchange of knowledge between undergraduate students of Pedagogy and students of different grades, based on the assumption that the construction of knowledge occurs through dialogue based on our reality.

Therefore, the construction of knowledge about the concepts of trigonometry and geometry took place in a meaningful and dynamic way, enhancing the skills and abilities of the students involved, bringing varied reflections on teaching practices based on contextualization. This showed us other conditions for thinking about teaching activities from 


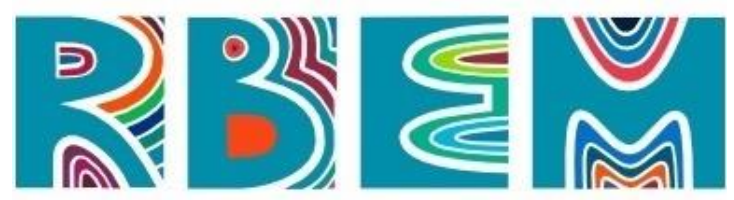

REVISTA BAIANA DE EDUCAÇÃO MATEMÁtICA

the perspective of the "arts of doing" that provokes us to think about school beyond its physical space as a possibility to expand horizons in relation to what is presented in it.

Thus, as Alves \& Garcia (2000) understand, the present study made it possible to understand how the school routine allows the theories learned in undergraduate training to be updated by contextualization experiences, making the teacher's knowledge a product of construction of the ways of inhabiting the profession, in view of the tactics and cunning necessary to make sense of what is taught at school.

Practices with experiences in the countryside gave the graduates with perspectives to seek to understand situations that provoke the search for other theoretical explanations and other ways of thinking about what happens between students and teachers, since they have the function of teaching and those of learning. And in the case of teachers in training, everyday life helps them to think about the theories they learn at the university and to develop them based on what the knowledge of school, of life, and of the countryside offers them. In this context, the knowledge of how the school is organized and works, makes the licensee develop another vision about this space, which is no longer seen in a perspective previously seen as a student and starts to see as a teacher in formation, but which establishes in itself an identity process that makes him become aware of teaching in the context of his development at school.

The educational and daily practices of teaching trigonometry in the countryside are understood by teachers in training as they appropriate the meanings constructed based on trajectories and knowledge linked to the experiences that the children reveal through the experience in the countryside and the understanding that they reveal to have of mathematics. This suggests that everyday life is taken as an element of inspiration and observation of how educational practices at school are operationalized in a logic that highlights the knowledge that the subjects involved develop when they perceive the relationship between students' learning and their own trajectories and cultural representations that they make of and in the daily life of the school.

\section{References}

ALVES, Nilda e GARCIA, Regina Leite (org.) et al. A Invenção da escola a cada dia. Rio de Janeiro, DP\&A, 2000. 


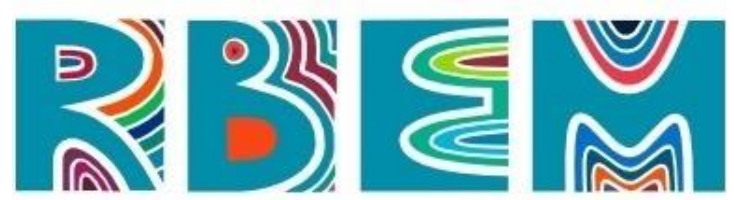

REVISTA BAIANA DE EDUCAÇÃO MATEMÁTICA

ALVES, Nilda. Tecer conhecimento em rede. In: ALVES, Nilda; GARCIA, Regina L. $O$ Sentido da escola. Rio de Janeiro: DP\&A, 2003, p. 91-100.

ALVES, Rafael Santana; CAVALCANTE, Kellison Lima. Educação contextualizada no ensino de matemática em uma escola no Semiárido de Juazeiro-BA. Revista Semiárido De Visu, v.5, n.1, p. 52-59, Juazeiro-Ba. 2017.

AUSUBEL, David P. A aprendizagem significativa: a teoria de David Ausubel. São Paulo: Moraes, 1982

BRASIL. Pró-letramento. Matemática. Disponível em: <http://portal.mec.gov.br/arquivos/pdf/fasciculo_mat.pdf>. Acesso em: 11 de agos. 2014.

CERTEAU, M. de. A invenção do cotidiano: 1, Artes de fazer. Petrópolis: Vozes, 1994.

GOMES, Antenor, R. e SILVA, Núbia. Imagem e conhecimento: Sentidos moventes, emergências e aprendizagem. Revista de Estudos Universitários, V.39 n.02. Brasil 2013. Disponível em: $<$ http://periodicos.uniso.br/ojs/index.php?journal=reu\&page=issue\&op=view\&path\%5B0\%5 $\mathrm{D}=150 \&$ path\%5B1\%5D=showToc $>$. Acesso em: 09 de jun. 2014.

HELLER, Agnes. Sociología de la vida cotidiana. Barcelona: Península, 1977.

MORETTO, Vasco Pedro. Prova: um momento privilegiado de estudo, não um acerto de contas. 5 ed. Rio de Janeiro: Dp \& A, 2007.

RIOS, Jane Adriana Vasconcelos Pacheco. Ser ou não ser da roça, eis a questão! Identidades e discursos na escola. Salvador: EDUFBA, 2011.

TUFANO, W. Contextualização. ln: FAZENDA, I. C. Dicionário em Construção: Interdisciplinaridade. São Paulo: Cortez, 2001.

VÁRZEA DO POÇO (BA). Decreto-lei no 09, de 19 de junho de 2015. Plano Municipal de Educação. Arquivo da SME/Várzea do Poço-Ba. 2015.

Artigo submetido em: 22/11/2020

Artigo aceito em: 22/12/2020

\footnotetext{
i Rios (2011, p. 21) conceives countryside as a specific rurality centered on the semiotics of the land, in which senses, itineraries, meanings and resignifications take place daily in different paths existing in a territory configured by "[...] a cartography that passes at the margins of the countryside, which marks passages, searches, borders, doing in different ways".

ii It is a site located in the municipality of Várzea do Poço, located at km 22 of the BA 417 Serrolândia / Várzea do Poço highway, which served as an experimental space for the development of the workshops.
} 